\title{
БАЛКАНСКИЕ ВОЙНЫ: ПОБЕДА И ПОРАЖЕНИЕ ДЛЯ БОЛГАРИИ (1912-1913)
}

\author{
Дженгиз Хаков
}

\begin{abstract}
Cengiz Hakov, Балканские войнь: победа и поражение для Болгарии (1912-1913) (The Balkan Wars - Victory and Defeat for Bulgaria (1912-1913)).

Balcanica Posnaniensia. Acta et studia, XIX, Poznań 2012, Wydawnictwo Instytutu Historii UAM, pp. 139-147, ISBN 978-83-63-047-17-7, ISSN 0239-4278. Russian text with a summary in English.

Cengiz Hakov, Институт по балканистика при БАН, София - Болгария..
\end{abstract}

На Балканском полуострове в течении чуть больше года велись две войны с противоположными целями и задачами. Первая война велась между государствами Балканского союза и Турцией, которая завершилась поражением Турции и заключением Лондонского мирного договора 17 мая 1913 года. Вторая война велась между Болгарией и ее союзниками, входящими в Балканский союз, так называемая Межсоюзническая война, которая завершилась поражением Болгарии и заключением Бухаресткого мирного договора от 28 июля 1913 года. ${ }^{1}$

22 сентебря 1908 года Княжество Болгария провозглашает независимость от Османской империи, а Фердинанд был провазглашен царем болгар. ${ }^{2} \mathrm{C}$ подписанием 19 апреля 1902 года в Стамбуле Турецко-Болгарского протокола Турция официально признает независимость Царства Болгарии. ${ }^{3}$ С этого момента перед царем Фердинандом и Царством Болгарии стоит историческая задача объединить всех болгар на Балканах в одном государстве. А это могло произойти только путем расширения территории царства за счет османских провинций на

${ }^{1}$ См. под стр.: Марков, Г. България и Балканският съюз срещу Османската империя 1912-1913. София. 1989; Марков, Г. „Балканизацията”. София. 2011; Хаков, Дж. История на Турция през XX век. София. 2000; Станев, Н. История на нова България 1878-1941. София. 1992; Спасов, Л. История на България 1878-1945. София. 2008; Тошев, А. Балканските войни. Том втори. ПловдивСофия. 1931; Генов, Г. П. Международни актове и договори, засягащи България. София. 1940.

${ }^{2}$ Генов, Г. П. Пос. соч., с. 347-353.

${ }^{3}$ Там же, с. 353. 
Балканах. Такую же политику стремятся проводит и другие балканские государства. Все они ищут поддержку Великих сил, которые имеют противоречивые интересы в решении так называемого „Восточного вопроса” - раздел османского наследства на Балканах. ${ }^{4}$

Для осуществления своих национальных целей Болгария проводит активную дипломатическую деятельность, чтобы получить поддержку России и союзников в лице других балканских государств. Официальная визита царя Фердинанда в феврале 1910 года в Петербурге не постигла всех намеченных целей. Потому что Россия, готовясь к надвигающейся мировой войне, не спешила с военными действиями против Турции и хотела привлечь Болгарию на стороне Антанты, против Тройного союза. Болгаро - сербские переговоры не продвигались из-за разногласий по македонскому вопросу. Пока Болгария отстаивала автономию Македонии, Сербия настаивала на ее разделение между двумя странами. Нельзя говорить о продвижении и в болгаро-греческих переговоров из-за претензий греков на Солониках и южных частей Македонии. Препятствием в продвижении болгаро-румынских переговоров являлись претензии Румынии на южную часть Добруджи. Чтобы усыпить бдительность Турции по отношению активной дипломатической деятельности Болгарии, в марте 1910 года царь Фердинанд сделал официальную визиту в Стамбул, чтобы подтвердить желание Болгарии о дальнейшем развитии добрососедских отношений между двумя странами.

16 сентября 1911 года Италия объявляет войну Турции для завоевания ее североафриканских провинций Триполитания и Киренайка. ${ }^{5}$ Пользуясь тем, что Турция вела войну с Италией, весной 1912 года под патронажем России был создан Балканский союз с участием Болгарии, Греции, Сербии и Черногории. Румыния осталась вне этого союза, преследуя свои цели, сообразно развитию военных действий против Турции. ${ }^{6}$

13 мая 1912 года был подписан Договор о союзе между Болгарией и Сербией, который был сопровожден военной конвенцией и секретным приложением. ${ }^{7}$ Этим договором Болгария обязывалась помочь Сербии 200 000-ой армией против Австро-Венгрии, Турции, Румынии, а Сербия обязывалась оказать помощь 150 000-ой военной силой Болгарии против Турции и Румынии. Согласно тайному приложению территории на востоке от Родопах и нижнего течения реки Струма признаются болгарскими, а на севере и северо-западе от горы Шар признаются сербскими. Территории между горами Шар, Родопи, Эгейского моря и Охридского озера были определены для автономной области Македонии.

16 мая 1912 года был подписан Договор о союзе между Болгарией и Грецией. ${ }^{8}$ Согласно военной конвенции к договору Болгария обязывалась действовать

\footnotetext{
4 Марков, Г. „Балканизацията”.....c. 24-78.

5 Хаков, Дж. Пос.съч. с.43.

6 Марков, Г. „Балканизацията”...,c.144-156.

7 Станев, Н. пос. соч., с. 190-191; Спасов, Л. пос. соч. , с. 34.

${ }^{8}$ Станев, Н. пос. соч., с. 195-196.
} 
против Турции 300 000-ой армией, а Греция - 120 000-ой армией. В отличии от Болгаро-Сербского договора, в этом договоре не говорится о разделе завоеванных территорий. 15 августа 1912 года была постигнута устная договоренность с Черногорией, чтобы она участвовала в войне с Турцией 40 000-ой военной силой. ${ }^{9}$ Таким образом окончательно формировался Балканский союз.

29 сентября 1912 года союзники вручают туправляющему дипломатическим представительством Османской империи в Софии коллективную ноту с требованием проведения реформ в балканских областях империи, с генераломгубернатором бельгийцем или швейцарцем, выборные областные собрания, жандармерия и местная полиция, свободное образованието. ${ }^{10}$

Союзники очень хорошо знают, что османское правительство отвергнет их ноту и это послужит поводом для начала военных действий. Вмешательство Великих сил с требованием проведения частичных реформ, чтобы избежать военных действий не дает резултатов. 3 октебря османское правительство отвечает, что нота стран Балканского союза не заслуживает ответа и прекращает дипломатические отношения с Болгарией и Сербией. В сущности это и было объявление войны этим странам. 5 декабря 1912 года Болгария, Сербия и Греция объявляют войну Турции. В тот же день в Швейцарии подписывается мирный договор между Турцией и Италией, который сразу же входит в силу. Великие силы, готовясь к предстоящей мировой войне, объявляют неутралитет в Балканской войне ${ }^{11}$

Так начинается Первая балканская война. На Восточно-фракийском фронте действуют три болгарские армии, чья численность превышает 300000 человек, а турецкие войска насчитывают 200 000. На македонском фронте численность войск Сербии, Греции, Черногории и ограниченный контингент болгарских войск насчитывают чуть больше 400000 человек, а турецкие войска - 150000 человек. Отдельно два болгарских отряда действуют между рек Марица и Струма против малочисленных турецких частей. При таком соотношении сил военные действия развиваются быстротой, неожиданной даже для самих воюющих сторон. На Восточно-фракийском фронте болгарские войска окружают Адрианополь и продвигаются к Стамбулу, 24 октября они остановлены у Чаталджи. Болгарские войска, действующие в Родопах и Западной Фракии, захватывают ряд городов и сел. А те, кто действуют в долине реки Струма приближаются к Солоникам. На Македонском фронте успешно действуют сербские, греческие и черногорские вооруженные силы. 27 октября турецкое командование сдает боя Солоники грекам. ${ }^{12}$

Менее чем за три недели почти все балканские территории Турции, за исключением крепостей Адрианополь, Шкодра и Янина, попадают в руки госу-

\footnotetext{
9 Спасов, Л. пос. съч. , с. 34.

10 Марков, Г. „Балканизацията”..., с. 180.

11 Марков, Г. , там же, с. 181-182.

12 Станев, Н. пос. соч., с. 170-174.
} 
дарств Балканского союза. 30 октября Турция обращается к Франции с просьбой посредничать в заключении перемирия. Царь Фердинанд, который находился вне Софии, телеграфировал болгарскому правительству, что „мир будет диктоваться в Стамбуле". ${ }^{13}$ По его приказу 5 и 6 ноября болгарские войска атакуют оборонительные линии турецких войск у Чаталджи и терпят поражение. 20 ноября между Болгарией и Турцией заключается перемирие, а 3 октября в Лондоне начинаются мирные переговоры между участниками Первой балканской войны. Условия мира, выдвинутые государствами Балканского союза следующие: Турция должна уступить все свои территории на Балканах на западе от линии Родосто (Текирдаг) на Мраморном море, Мидия (Мидие) на Черном море, свои острова в Егейском море, а также остров Крит; будущее Албании решается Велкими силами. Согласно турецким предложениям о мире вилает Адрианополь остается под турецким управлением, Македония превращается в вассальное султану княжество, Албания получает статус автономной области, Егейские острова остаются под управлением Турции; вопрос об острове Крит должен решиться между Турцией и Великами силами. ${ }^{14}$

При таком большом различии в предложениях двух переговаривающих сторон заключение мира стало невозможным. 10 января 1913 года младотурецкая партия „Единение и прогресс” совершает переворот в Турции. ${ }^{15}$ Новое турецкое правительство не согласно удовлетворить требования государств Балканского союза о Восточной Фракии и Адрианополе. 12 января Румыния требует исправление румыно-болгарской границы в районе Добруджи в свою пользу по линии Тутракан-Балчик. 17 января мирные переговоры в Лондоне прерываются и военные действия возобновляются. 24 января турецкие войска безуспешно атакуют болгарские позиции в районе Чаталджи. Безуспешный был и десант младотурок в районе Шаркёй. Греческие войска берут Янину без боя. 11 марта болгарские войска берут осажденный с начала войны Адрианополь с участием 50 000-ого сербского корпуса. 1 апреля 1913 года боевые действия между Болгарией и Турцией прекращаются.

В результате возобновления мирных переговоров в Лондоне 17 мая 1913 года был заключен подготовленный Великими силами мирный договор между Турцией и государств Балканского союза.. ${ }^{16}$ Согласно этому договору Турция отказывается в пользу Балканского союза от своих территорий на западе от линии Энос на Егейском море до Мидии на Черном море, за исключением Албании, котороя провозглашает свою независимость. Великим силам предоставляется определить границы Албании и решать все вопросы, связанные с ее независимым существованием. Турция отказывается от своих прав на острове Крит и егейских островах в пользу Великих сил. Все финансовые вопросы, связан-

\footnotetext{
13 Спасов, Л. пос. соч. , с. 35.

14 Тошев, А. пос. соч., с. 391, 395.

15 Хаков, Дж. пос. соч., с. 44-45.

16 Тошев, А. пос. соч., с. 391-399.
} 
ные с окончившейся Балканской войной, должны решаться в Париже международной комиссией.

Заслуги за победу в кончившейся Балканской войне имеют все государства Балканского союза, но прежде всего Болгария, которая принимает участие в войне с самыми многочисленными вооруженными силами и побеждает основные силы противника. После войны Болгария превращается в самое большое балканское государство по отношении территории и населения, чем были недовольны другие балканские государства. Они воспользовались недостатками допломатической подготовки войны, чтобы пересмотреть ее результаты.

Из предварительных дипломатических переговоров только в Договоре о союзе и дружбе между Болгарией и Сербией определены территории, которые они будут делить между собой после окончания войны. После создания независимого Албанского государства Сербия не может получить ожидаемые территории на севере и западе от горы Шар и поэтому хочет компенсировать их за счет территорий в Македонии. При этом Сербия подчеркивает свой дополнительный вклад в победу благодаря участии 50 000-ого сербского корпуса во взятии Адрианополя, который остается в границах Болгарии. Греция после взятия Солоник без боя претендует на часть македонских территорий, которые были предусмотрены, согласно договору между Сербией и Болгарией, для Болгарии. Румыния со своей стороны претендует на Южную Добруджу. Турция внимательно следит за нарастающими противоречиями между странами Балканского союза и готовится вернуть Восточную Фракию и Адрианополь. Два дня после заключения Лондонского мирного договора, 19 мая 1913 года Сербия и Греция заключают союзный договор и военную конвенцию взаимопомощи против Болгарии. Чтобы предотвратить распад Балканского союза, Россия предлагает его членам разоружиться и в Санкт-Петербурге под русским патронажем решить взаимные территориальные претензии. ${ }^{17}$

Таким образом после войны Болгария оказывается в исключительно тяжелом положении. Царь Фердинанд и его первый помощник ген. М. Савов решают выйти из этой тяжелой ситуации путем успешной карательной военной акции против Сербии и Греции, чтобы вынудить их стать более сговорчивыми по спорным территориальным вопросам. В ночь 16 на 17 июня 1913 года болгарские военные части нападают на сербские и греческие войска без официального объявления войны. Так начинается Вторая балканская (Межсоюзническая) война. В ней Болгария принимает участие четырьмя армиями общей численностью 500500 человек, рассположенными на широком фронте от Кавалы на Егейском море до Видина на реке Дунай. Болгарским армиям противостоят греческие, сербские и черногорские войска общей численностью 590000 человек. Сначала болгарские войска добиваются успеха на отдельных участках фронта, но неожиданное сопротивление противника заставляет болгарское командование остановить военные действия. Однако сербские и греческие войска воспользо-

17 Пак там, с. 401-405. 
вались создавшейся обстановкой на фронте и не остановили военные действия. Даже больше, 21 июня Греция и 25 июня Сербия официально объявляют войну Болгарии. 27 июня Румыния объявляет войну Болгарии и ее войска захватывают Южную Добруджу, а другие ее военные части переходят Дунай и оказываются в непосредственной близости от Софии. Спустя месяца после подписания Лондонского мирного договора турецкие войска возвращают себе Восточную Фракию и Адрианополь. А отдельные турецкие военные части переходят на западе от реки Марица и захватывают территории Восточных Родоп и Западной Фракии. ${ }^{18}$

Болгария, будучи окруженной своими соседями, была вынуждена 17 июля 1913 года заключить перемирие. На этот раз переговоры ведутся не в Лондоне, а в Бухаресте с участием Румынии, Сербии, Греции и Черногории с одной стороны и Болгарии с другой, под закулисным руководством Великих сил. 28 октября заключается Бухарестский мирный договор, согласно которому Южная Добруджа остается в Румынии и новая граница проходит по линии Тутракан на реке Дунай - Балчик на Черном море. Новая болгаро-сербская граница начинается на севере от вершины Патарница, следует вниз между реками Вардар и Струма и кончается на горе Беласица, где связывается с болгаро-греческой границей. Болгаро-греческая граница начинается от Беласицы, продолжает к востоку и кончается у вливания реки Места в Егейском море. Территории в Восточных Родопах и Западной Фракии, между реками Места и Марица остаются в Болгарии. ${ }^{19}$

После заключения Бухаресткого мирного договора Болгарии предстоит регулировать свои отношения с Турцией. Она обращается к участникам прежней Лондонской мирной конференции, чтобы заставили Турцию вывести войска за линией Энос-Мидия. Царь Фердинанд обращается с отчаянным призывом к Австро-Венгерскому императору Францу Йосифу защитить Болгарию от турков. ${ }^{20}$ Однако участники Тройного союза и Антанты не были заинтересованы накануне Первой мировой войны оказать давление на Турцию во имя Болгарии. Поэтому 24 июля 1913 года участники Лондонской мирной конференции объявляют формальное решение уважать Лондонский мирный договор и отвести турецкие войска за линией Энос-Мидия. ${ }^{21}$ Однако они не принимают никаких практических мер, чтобы выполнить это решение. Только Россия предлагает оказать давление на Турцию путем внушительной демонстрации боевых единиц военно-морского флота Великих сил. Россия также предлагает организовать финансовый бойкот Турции.

\footnotetext{
18 Станев, Н. пос. соч., с. 218.

19 Тошев, А. пос. соч., с. 401-417.

${ }^{20}$ Влахов, Т. Турско-българските отношения през 1913-1915. Сп. Исторически преглед, година XI. Книга I. София. 1955. с. 6-10.

${ }^{21}$ Там же, с. 24-25.
} 
Противоречивые интересы Великих сил делают предложение России невыполнимым. Даже больше, Германия заявляет, что вопрос о Восточной Фракии является внутренним вопросом Турции. 22

Болгария, надеясь на поддержку участников Лондонской конференции, отбрасывает любые двусторонные переговоры с Турцией о заключении мирного договора. Болгария не только не получила поддержку, но и была посоветована согласиться на прямые переговоры с Турцией. Даже Россия, которая была изолирована от других Великих сил, тоже посоветовала регулировать отношения с Турцией. ${ }^{23}$ Болгария, оставшись без поддержки Великих сил, принимает турецкое предложение о начале двусторонних переговоров как о заключении мирного договора, так и по остальным политическим и экономическим вопросам, интересовавших двух стран. ${ }^{24}$

Болгарская делегация приезжает на переговоры в Стамбул в начале сентября 1913 года. Еще при проводов болгарской делегации на вокзале в Софии царь Фердинанд сказал генералу Савову о необходимости подписания не только мирного договора, но и тайного политического договора между Болгарией и Турцией. ${ }^{25}$ Еще в самом начале переговоров турецкие предложения о мирном договоре и предложения о новой турецко-болгарской границе формулируются по принципу „что взяли, то наше”. Талят паша - руководитель турецкой делегации, обращаясь к руководителю болгарской делегации генралу Савову добавил "Ничего не даете из своего кармана, отступите нам Адрианополь как знак доброй воли". ${ }^{26}$ Другими словами, Восточная Фракия и Адрианополь принадлежат Турции, поэтому Болгария ничего собственного не теряет.

Еще с самого начала переговоров болгарской делегации было ясно, что вопрос о территориях Восточной Фракии и о новой болгаро-турецкой границы уже предрешен и она не сможет сделать ничего по этому вопросу. Но учитывая насколько важно для Болгарии выходить на Эгейское море, она ставит вопрос об отходе турецких войск из Западной Фракии на левый берег реки Марица. Тем более, что согласно Бухаресткому договору эта территория с городами Дедеагач, Гюмюрджина и Ксанти отданы Болгарии. Однако Турция отказывается вывести войска раньше окончания переговоров и определения новой турецкоболгарской границы, а также гарантирования прав турецко-мусульманского населения в Болгарии и в новых землях. ${ }^{27}$

22 Там же, с. 14.

23 Там же, с. 20.

24 Дипломатически документи по намесата на България в европейската война. Том I, 1913-1915. София, 1920, с. 43.

25 Тошев, А. По сключването на Цариградския мирен договор в 1913 г. сп. Българска мисъл, София, 1930 г., кн. 2, с. 101.

26 Там же, с. 105.

27 Централен Дьржавен Архив (ЦДА), ф. 176К, оп.2, а. е. 1391, л. 171. 
29 сентября 1913 года происходит торжественное подписание болгаротурецкого мирного договора делегациями двух стран. ${ }^{28}$ Согласно статьи 1 этого договора новая граница между Болгарии и Турции начинается с устьи реки Резовска на Черном море, идет на Запад по горе Странджа, обходит Адрианополь с северо-запада, спускается вниз по реке Марица и через ее правый рукав доходит до Егейского моря. Оба государства обязуются вывести войска из территорий, принадлежащих другой стороне в течении 15 дней (ст.2). Все мусульмане, являющиеся болгарскими подданными, будут пользоватся теми же политическими и гражданскими правами, что и все остальные граждане Болгарии (ст.8). Болгарские общины в Турции будут пользоватся теми же правами, как и остальные христианские общины Турции (ст.9). Постановления Лондонского мирного договора действуют в той мере, в какой они не отменяют или видоизменяют постановления данного договора (ст.19). Другими словами, Царьградский мирный договор отменяет прежнюю граничную линию Энос-Мидия, которая была определена Лондонским мирным договором. Настоящий мирный договор входит в силу сразу после подписания, а ратификационные документы обмениваются в течение 15 дней.

В связи с подписанием Царьградского мирного договора 1913 года главы государств Болгарии и Турции обмениваются поздравлениями. Царь Фердинанд говорит:" Этот акт ознаменовал конец наших старых и новых разногласий , открывает новую эпоху мира и дружбы между нашими двумя государствами."29 Со своей стороны, султан Мехмет V сказал:" Этот договор ставит начало счастливого будущего и дружеских отношений между двумя народами."”30

Подводя итоги, надо сказать, что Балканские войны коренным образом изменили географическую карту Балканского полуострова. Выигравшими оказались Греция, которая увеличила свою территорию на 91\%, а население увеличилось на $67 \%$ и Сербия, которая увеличила территорию на $80 \%$, население увеличилось на $41 \%$. Румыния практически без каких либо военных действий присоединила Южную Добруджу к своим территориям. Болгария, которая вела тяжелейшие сражения против Турции и у нее больше всех погибших, в конце концов увеличила свою территорию всего на $17 \%$ и население - на $8 \% .{ }^{31}$ Самыми большими потерями из войны вышла Турция, которая потеряла все свои балканские территории за исключением Восточной Фракии и Адрианополя. Балканский союз, созданный против Турции, распадается, противоречия между балканскими государствами еще больше углубляются и это их снова противопоставляет в Первой мировой войне, кончившейся катастрофальными последствиями для Болгарии и Турции.

\footnotetext{
${ }^{28}$ Стефанова, С. Международни актове и договори (1648-1918). София, 1958, с. 333-338.

29 Тошев, А. пос. соч., с., с. 469.

30 Там же.

31 Марков, Г. „Балканизацията”...., с. 236.
} 


\title{
THE BALKAN WARS - VICTORY AND DEFEAT FOR BULGARIA (1912-1913)
}

\author{
Summary
}

After declaring its independence in 1908, in the name of the unification of all Bulgarians in one state Bulgaria carried out a policy of expanding its territory at the expense of the Ottoman provinces in the Balkans. The same policy was followed by all the other Balkan states. In the spring of 1912 under Russian auspices was formed the Balkan Alliance in which took part Bulgaria, Serbia, Greece and Montenegro. In the course of one year two wars with opposite goals and objectives were waged in the Balkans. The first war was between the states from the Balkan Alliance and Turkey, and the second - between Bulgaria and its allies from the Balkan Alliance. The Balkan wars changed radically the map of the Balkans. The Balkan Alliance disintegrated, the contradictions among the Balkan states aggravated and that again set them against each other in the First World War.

\section{WOJNY BAŁKAŃSKIE: ZWYCIĘSTWO I KLĘSKA BUŁGARII (1912-1913)}

\section{Streszczenie}

Po ogłoszeniu niepodległości Bułgarii w 1908 roku car Ferdynand w imię zjednoczenia wszystkich Bułgarów w jednym państwie podjął politykę zjednoczenia wszystkich Bułgarów w jednym państwie kosztem prowincji osmańskich na Bałkanach. Podobną politykę prowadziły i inne państwa bałkańskie zachęcane przez wielkie mocarstwa, posiadające przeciwstawne interesy na Bałkanach. Wiosną 1912 roku pod opieką Rosji utworzony został Związek Bałkański, w którym uczestniczyły Bułgaria, Grecja, Serbia i Czarnogóra.

W przeciagu ponad roku na Bałkanach prowadzone były dwie wojny, które miały sprzeczne ze sobą cele i zadania. Pierwsza wojna toczyła się między państwami bałkańskimi a Turcją która zakończyła się klęską Turcji i zawarciem w maju 1913 roku Druga prowadzona była między Bułgarią a jej sojusznikami ze Związku Bałkańskiego, tzw. wojna międzysojusznicza, zakończyła się klęską Bułgarii i zawarciem pokoju w Bukareszcie w lipcu 1913 roku.

Wojny bałkańskie zmieniły zasadniczo mapę geograficzną Bałkanów. Turcja straciła prawie wszystkie swoje bałkańskie terytoria, a Bułgaria większą część terytoriów zdobytych w czasie pierwszej wojny. Grecja, Serbia, Czarnogóra i Rumunia znacznie powiększyły swoje terytoria i swoją ludność. Rozpad Związku Bałkańskiego zaostrzył też przeciwieństwa między państwami bałkańskimi, co stało się widoczne w pierwszej wojnie światowej, umożliwił on jednak zarazem zbliżenie polityczne Turcji i Bułgarii, co przypieczętował zawarty między tymi państwami pokój w Stambule - 29 września 1913 roku. 
